\title{
ANTIBODY RESPONSE IN UVEITIS
}

\author{
YVONNE DE KOZAK \\ Paris, France
}

The role of antibodies in uveitis is controversial. Indeed, antibodies directed at specific organisms or autoantigens could either participate in the pathogenesis or in the suppression of uveitis or could be interpreted as an epiphenomenon resulting from other processes. We will examine the role of antibodies in experimental models of uveitis: experimental autoimmune uveoretinitis (EAU), endotoxininduced uveitis (EIU) and ocular inflammatory disorders developed in humans.

\section{ROLE OF ANTIBODIES IN THE INDUCTION OF EAU}

EAU has been described as a mainly T-cell-mediated disease. Immunisation of rats with retinal autoantigens (S-antigen (S-Ag), interphotoreceptor retinoidbinding protein (IRBP), rhodopsin, melanin-bound antigen) results in the activation of retinal-antigen specific Th1-like lymphocytes associated with delayed-type hypersensitivity to the immunising antigen. ${ }^{1-3}$ The role of antibodies in the induction of EAU lesions is not clearly understood. Several lines of evidence indicate a role for antibodies in EAU induction:

1. A single immunisation with retinal autoantigens induces high titres of circulating antibodies directed at different epitopes of the S-Ag molecules from the second week after immunisation. ${ }^{4}$

2. Injection of hyperimmune serum to rod outer segments either in the eye or systemically results in moderate EAU. ${ }^{5}$ Intravenous injection of a polyclonal rat serum anti-S-Ag to a normal rat or administration of this antibody to rat eyecup preparations by bolus perfusion induces electroretinographic supernormality, indicating a direct consequence of immunoglobulin binding to its target protein and interaction with cell-surface receptors of molecules involved in photoreceptor function. ${ }^{6}$

Correspondence to: Y. de Kozak, Laboratoire d'Immunopathologie de L'Oeil, Centre Biomédical des Cordeliers, 15, rue de L’Ecole de Médecine, F-75270 Paris Cedex 06, France.
3. The massive neutrophil infiltration in acute EAU might result from an immune-complex-mediated reaction, as suggested by the suppression of neutrophil infiltration by complement depletion using cobra venom factor. ${ }^{7}$ However, circulating immune complexes (CIC) could be involved in both the regulation and pathogeny of EAU. ${ }^{8}$

4. IgE antibodies specific for S-Ag, detected early in the serum of S-Ag immunised rats, may play a role in the initiation of EAU by mediating local mast cell degranulation ${ }^{9}$ and release of multifunctional cytokines ${ }^{10}$ which have a role in recruitment of leucocytes. The role of mast cells in the induction of EAU is further supported by several findings: mast cell degranulation occurs before the onset of EAU, ${ }^{9}$ development of EAU is lowered by drugs that affect mast cells ${ }^{11}$ and the number of mast cells in rat choroid, ${ }^{12}$ iris and ciliary body is correlated with the susceptibility of rats to EAU. ${ }^{13}$

These data would be in favour of a role of antibodies in EAU induction. However, adoptive transfer of EAU is effective with $\mathrm{T}$ cells without the presence of antibodies in recipients (Mochizuki ${ }^{1,14}$ and several reports indicate a participation of antibodies in disease suppression).

\section{ROLE OF ANTIBODIES IN THE IMMUNOSUPPRESSION OF EAU}

Regulation of EAU by Local Synthesis of Antibodies Guinea pigs and monkeys present a chronic and subacute form of EAU characterised by lesions of photoreceptor cells with focal infiltrations of mononuclear cells of the choroid. After the acute phase of EAU, plasma cells are the most numerous cells found in the choroid infiltrates that can be detected for long periods of time in healing lesions (Fig. 1). Indeed, as detected by monoclonal antibodies directed at guinea pig leucocyte antigens, a progressive increase in B cells associated with a decrease in suppressor/cytotoxic $\mathrm{T}$ cells is observed in late stages of EAU. ${ }^{15}$ These findings are in favour of a role of 


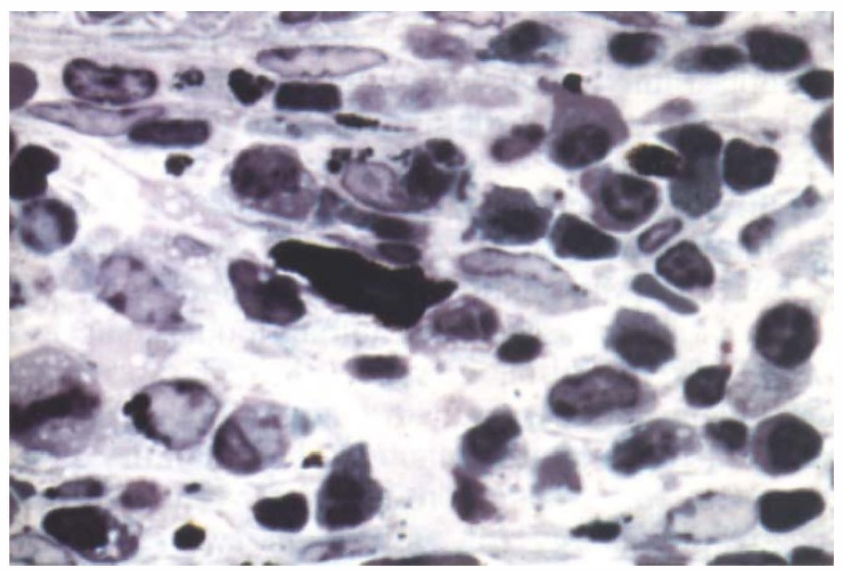

Fig. 1. Two months after one injection of purified bovine photoreceptor cells in complete Freund's adjuvant into guinea pig footpads, choroidal inflammatory infiltrate containing numerous plasmocytes is seen.

antibodies in local down-regulation on the ocular immune response.

\section{Regulation of EAU by Antibodies Directed Against Cellular Components}

Effective inhibition of EAU has been reported after treatment with antibodies directed at a variety of surface molecules expressed on cells participating in the immune reaction. Antibodies used for EAU treatment were directed against $\mathrm{CD} 4,{ }^{16}$ class II M antigen, ${ }^{17,18}$ interleukin-2 (IL-2) receptor, ${ }^{19}{ }^{\mathrm{TCR}^{20}}$ and adhesion molecules ICAM-1 and LFA- $1{ }^{21}$ These antibodies are possibly acting through an inactivation of molecules expressed on ocular resident and/or inflammatory cells that express these surface molecules during the inflammatory process.

\section{Regulation of EAU by Manipulation of the Idiotypic Network}

According to the network theory of Jerne, ${ }^{22}$ interactions of idiotypes and anti-idiotypes, at humoral and cellular level, participate in the regulation of the immune response. Schematically, immunisation with an antibody directed against an antigenic determinant (epitope) of an antigen results in the formation of an anti-antibody (anti-idiotype, anti-Id) recognising the hypervariable domain (idiotype) of the immunising antibody. This anti-Id, called the 'internal image' of the antigen, mimics the antigen through its stereochemical structure (Fig. 2).

Antibodies of different anti-idiotypic specificities have been shown to down-regulate EAU. ${ }^{23-26}$ This inhibitory effect on EAU was obtained by injecting rats simultaneously with the immunising $\mathrm{S}-\mathrm{Ag}$ or with a rat polyclonal antibody to S-Ag prepared in conditions that do not produce disease, or with mouse monoclonal antibodies $(\mathrm{mAb})$ directed at certain epitopes of S-Ag. ${ }^{23}$ The mAb S2D2 was the most effective in EAU inhibition. Immunisation

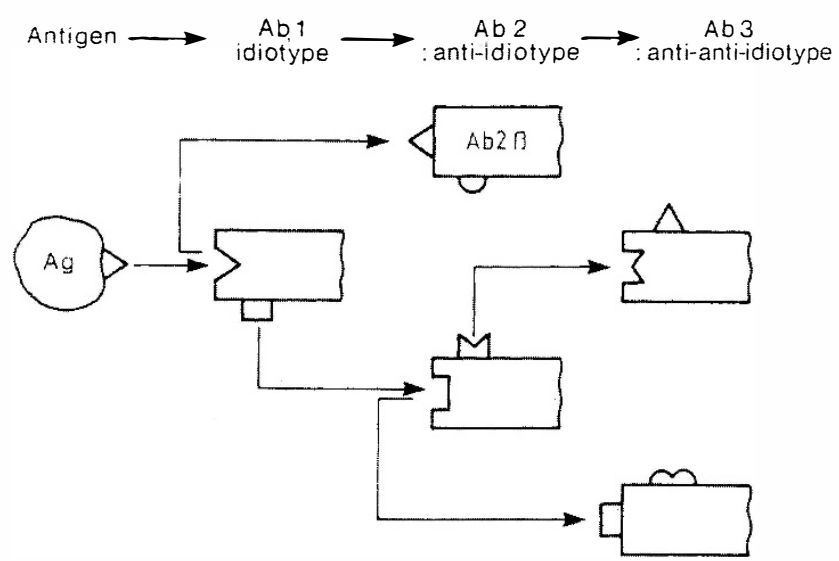

Fig. 2. Regulation of the immune response by interaction of idiotypes and anti-idiotypes (theory of idiotypic network). Ag, antigen; AB, antibody.

against the mAb S2D2 (three injections in complete Freund's adjuvant) prevented EAU induced by the injection of the whole molecule of $\mathrm{S}-\mathrm{Ag}^{24}$ This protocol allowed the production of high levels of anti-Id antibodies, as demonstrated in an immunoassay (ELISA) by competition of anti-Id contained in rat sera with labelled S-Ag for the plate-coated $\mathrm{mAb}$ containing the Id. EAU suppression could be adoptively transferred by cells (anti-Id cells) from donors immunised with a polyclonal antibody directed at $\mathrm{mAb} \mathrm{S2D} 2$ to recipients challenged with S-Ag. Lymph node cells from rats hyperimmunised with this anti-Id S2D2 antibody proliferated in the presence of anti-Id S2D2, mAb S2D2 and S-Ag. The suppressive effect of treatment with mAb S2D2 could result from an effect on the humoral and cellular immune network.

Interestingly, the most effective $\mathrm{mAb}$ responsible for EAU suppression - S2D2 - recognises an epitope (S2) situated in the N-terminal region of $\mathrm{S}-\mathrm{Ag}$ (contained in peptide $\mathrm{S} 2$, amino acid sequence 40-50 of bovine S-Ag; peptide 4, 31-50 of human $\mathrm{S}-\mathrm{Ag}$; peptide 5, 41-60 of human S-Ag). This sequence is distant from the known pathogenic sites. The S2 epitope displays a sequence homology with an epitope of tumour necrosis factor alpha (TNF- $\alpha$ ) (amino acid sequence 39-45 of human TNF- $\alpha$, peptide RRAN). Peptides from S-Ag and TNF- $\alpha$ containing this common epitope have been shown to stimulate TNF- $\alpha$ mRNA expression and TNF- $\alpha$ release by human monocytes in vitro. ${ }^{27,28}$

It has to be noted that antibodies directed against the homologous sequence in S-Ag (peptides S2, 4, 5) and TNF- $\alpha$ are detected in the serum of rats simultaneously injected with $\mathrm{S}-\mathrm{Ag}$ and mAb S2D2 and not developing EAU. ${ }^{4}$ Idiotypic regulation by S2D2 would induce cells reactive to S2D2 and anti-S2D2 mimicking the S-Ag/TNF- $\alpha$ epitope and antibodies, internal image of epitope S2 and RRAN (Ab2), inducing Ab3 (anti-peptide S2 and RRAN) 
responsible for the blockade of TNF- $\alpha$ and suppression of TNF- $\alpha$ mediated inflammation. This regulation of EAU by immunointervention on the idiotypic and cytokine networks could give an explanation for the suppressive effect of mAb S2D2 on EAU. Indeed, TNF is detected in aqueous humour and vitreous body at the onset of EAU ${ }^{29}$ and could originate either from ocular resident cells, retinal Müller glial cells and retinal pigmented epithelium ${ }^{30}$ in the posterior segment of the eye and/or from infiltrating inflammatory cells. ${ }^{29,31,32}$

\section{Prevention of Uveitis by Human Immunoglobulin Preparations for Intravenous Use}

Human immunoglobulin preparations for intravenous use (IVIg, Sandoglobulin, Central Laboratories of the Swiss Red Cross, Bern, Switzerland) are preparations of normal polyspecific IgG obtained from large pools of healthy donors. IVIg have been shown to be an efficient therapy for immuodeficiency, bacterial infections ${ }^{33}$ and a variety of autoimmune diseases, both organ specific and systemic. ${ }^{34,35}$ The beneficial effect of IVIg administration has been demonstrated in clinical situations such as idiopathic thrombocytopenic purpura, ${ }^{34-36}$ chronic inflammatory demyelinating polyneuropathy $^{37}$ and Kawasaki disease. ${ }^{38}$ IVIg treatment was also shown to improve the clinical signs of ocular inflammation observed in birdshot retinochoroidopathy. ${ }^{39}$

IVIg have been demonstrated to protect against EAU in rat $^{40}$ a Th1 cell dependent autoimmune disease in which high levels of IL-2, IL-4, interferon gamma (IFN- $\gamma$ ) and TNF are produced in response to $\mathrm{S}-\mathrm{Ag}$ immunisation. ${ }^{41,42}$ This experimental model is considered an experimental model for various human ocular diseases with an autoimmune component such as sympathetic ophthalmia, VogtKoyanagi-Harada syndrome and birdshot retinochoroidopathy. Five daily infusions of IVIg starting on the same day as $\mathrm{S}-\mathrm{Ag}$ immunisation protected rats against EAU, decreased lymphocyte proliferation S$\mathrm{Ag}$ and Concanavalin $\mathrm{A}$ and the antibody response to S-Ag, and inhibited IL-2 production by lymphocytes in the presence of S-Ag. This suppression was not dependent upon generation of suppressor cells. ${ }^{40}$

IVIg infusions were also shown to be effective in an ocular inflammation induced in rats by systemic injection of the lipopolysaccharide component of Gram-negative bacterial outer membranes: endotoxin-induced uveitis (EIU; unpublished data). In this ocular inflammation associated with the release of numerous cytokines, mainly IL-1, IL-6 and TNF- $\alpha,{ }^{29-31}$ five intravenous injections of IVIg, the last given at the same time as LPS challenge, inhibited EIU and TNF synthesis in serum and ocular media. In vitro experiments demonstrated that
IVIg can suppress the necrotising activity of TNF on fibroblast line L-929 and inhibit TNF production by retinal Müller glial cells stimulated in vitro by LPS + IFN- $\boldsymbol{\gamma}^{30}$

Different mechanisms might be involved in the inhibitory effect of IVIg on EAU and EIU. The presence in IVIg of anti-idiotypic antibodies directed against disease-associated autoantibodies suggests that IVIg might be effective through $\mathrm{V}$ regiondependent interaction with autoantibodies and/or receptors on $\mathrm{T}$ and $\mathrm{B}$ cells. ${ }^{35,43}$ The inhibitory effect of IVIg was related to a state of functional inactivation/anergy of $\mathrm{T}$ lymphocytes. Indeed, lymph node cells from IVIg-treated rats did not proliferate in the presence of $\mathrm{S}-\mathrm{Ag}$ and did not secrete IL-2 after antigen stimulation; protection was not related to suppressor cells. The protective effect could also be due to the ability of IVIg to suppress the production of numerous cytokines, mainly TNF- $\alpha$, IL- $1 \alpha,{ }^{44,45}$ IL- $6,{ }^{46}$ IL-2, IFN- $\gamma$ and lymphotoxin. $^{47}$ Autoantibodies directed against different antigenic specificities including anti-TNF, anti-IL-1 $\alpha$ and anti-IL-8 are present in the serum from healthy individuals. ${ }^{48}$ The presence in IVIg of antibodies to adhesion molecules ${ }^{49}$ and to $\mathrm{CD} 4,{ }^{49}$ which are expressed in ocular tissue during $\mathrm{EAU}^{21}$ and EIU, ${ }^{50,51}$ might play a role in the inhibitory activity of IVIg in EAU and in EIU, suggesting an effect of IVIg through the $\mathrm{V}$ region. Reversible $\mathrm{Fc}$ receptor blockade by infused IVIg might also be operative as observed in autoimmune cytopenias. ${ }^{34,35,52}$ The beneficial effect of IVIg on EAU and EIU could be related to the blockade of $\mathrm{Fc}$ receptors on cells of the reticulo-endothelial system and possibly on ocular resident cells such as epithelium of the iris/ ciliary body and retinal Müller glial cells.

Interestingly, patients with birdshot retinochoroidopathy treated with IVIg for long periods of time (12-53 months) show an improvement in visual acuity without side effects. ${ }^{53}$ IVIg therapy might represent an alternative in the treatment of birdshot retinochoroidopathy.

\section{ANTIBODIES TO RETINAL ANTIGENS IN HUMAN UVEITIS}

According to the network theory of Jerne, autoantibodies and anti-Id antibodies are present in serum from normal individuals. Indeed, natural antibodies to retinal antigens are detected in the healthy population. ${ }^{54-56}$ Antibodies to $\mathrm{S}-\mathrm{Ag}$ (detected by ELISA) are found in patients with uveitis, ${ }^{57,58}$ but no clear difference is detected between patients and controls. ${ }^{54-56}$ However, other reports show that antibodies to retinal antigens are involved in pathological manifestations. Autoantibodies against ocular antigens are demonstrated by immunostaining techniques in Vogt-Koyanagi- 
Harada (VKH) syndrome and in Behçet's disease, selectively binding the outer portion of the retina. ${ }^{59}$ Antibodies found in patients with Behçet's disease adhere to the lip of guinea pigs ${ }^{60.61}$ and might not be specific to Behçet's disease as they are found in other inflammatory situations. ${ }^{62}$ Patients with retinal vasculitis present antibodies to $\mathrm{S}-\mathrm{Ag}$ with lower affinity than controls. ${ }^{63}$ In the serum of patients suffering from cancer-associated retinopathy (CAR), antibodies to recoverin and visinin have been detected. ${ }^{64}$ Recoverin is a calcium-binding protein of rod outer segments and visinin may be the cone homologue of recoverin and could be the CAR antigen in cones. Autoantibodies from patients with CAR are directed at tumour antigens and cross-react with shared epitopes in the nervous system, inducing degeneration of the photoreceptors. In serum from patients suffering from cutaneous melanoma-associated retinopathy (MAR), autoantibodies against a melanoma antigen cross-react with bipolar cells and induce abnormalities of the rod and cone systems that are specific for MAR. ${ }^{65}$

\section{IMMUNE COMPLEXES IN UVEITIS}

Circulating immune complexes have been detected in inflammatory situations including Behçet's disease, ${ }^{66.67}$ and have been demonstrated in the eye. ${ }^{67.68}$ However, in recent reports low levels of circulating immune complexes were detected in the serum of patients with severe retinal vasculitis while high titres of immune complexes often correlate with mild inflammation..$^{57,69}$ As proposed by the authors, this finding could indicate that immune complexes are composed of idiotypic and anti-idiotypic antibodies representing a defence against potential harmful effects of antibodies.

The role of retinal antibodies in the development of uveitis, regulatory or epiphenomenal, is speculative. However, new prospects for diagnosis and treatment could arise from analysis of the immune response of patients to retinal antigens and their fragments ${ }^{70}$ the determination of new retinal antigens involved in pathology such as CAR antigen, and from immunointervention on the idiotypic and cytokine networks.

\section{REFERENCES}

1. Caspi RR, Roberge FG, McAllister CC, El Saied M, Kuwabara T, Gery I, Hanna E, Nussenblatt RB. T cell lines mediating experimental autoimmune uveoretinitis (EAU) in rat. J Immunol 1986;136:928-33.

2. Faure JP. Autoimmune disease of the retina. In: Bona CA, Siminovitch KA, Zanetti M, Theofilopoulos AN, editors. The molecular pathology of autoimmune diseases. Langhorne, PA: Harwood Academic, 1993: 651-72.

3. Pepose JS, Holland GN, Wilhelmus KR. Ocular infection and immunity. St Louis: Mosby, 1996.
4. de Kozak Y, Stiemer RH, Mirshahi M, Frank RM, de Smet M, Faure JP. Humoral immune response against the S-antigen/TNF- $\alpha$ common epitope in rat EAU suppressed by the monoclonal antibody S2D2. Curr Eye Res 1992;11:119-27.

5. de Kozak Y, Yuan WS, Bogossian M, Faure JP. Humoral and cellular immunity to retinal antigens in guinea pigs. Mod Probl Ophthalmol 1976;16:51-8.

6. Stanford MR, Robbins J, Kasp E, Dumonde DC. Passive administration of antibody against retinal Santigen induces electroretinographic supernormality. Invest Ophthalmol Vis Sci 1992;33:30-5.

7. Marak GEJ, Waker WB, Rao NA, Jack R, Ward PA. Effects of complement depletion on experimental allergic uveitis. Ophthalmol Res 1979;11:97-107.

8. Kasp E, Stanford MR, Brown E, Coombes AGA, Dumonde DC. Circulating immune complexes may play a regulatory and pathogenic role in experimental autoimmune uveoretinitis. Clin Exp Immunol 1992; 88:307-12.

9. de Kozak Y, Sainte-Laudy J, Benveniste J, Faure JP. Evidence for immediate hypersensitivity phenomena in experimental autoimmune uveoretinitis. Eur J Immunol 1981;11:612-7.

10. Gordon JR, Burd PR, Galli SJ. Mast cells as a source of multiple functional cytokines. Immunol Today 1990;11: 458-64.

11. de Kozak Y, Sainte-Laudy J, Benveniste J, Faure JP Pharmacological modulation of IgE-dependent mast cell degranulation in experimental autoimmune uveoretinitis. Jpn J Ophthalmol 1983;27:598-608.

12. Mochizuki M, Kuwabara T, Chan CC, Nussenblatt RR, Metcalfe DD, Gery I. An association between susceptibility to experimental autoimmune uveitis and choroidal mast cell numbers. J Immunol 1984;133:1699-701.

13. Li Q, Caspi RR, Najafian F, Nussenblatt RR, Chan CC. Association between mast cells and the development of experimental autoimmune uveitis in different rat strains. Clin Immunol Immunopathol 1992;65:294-9.

14. Mochizuki M, Kuwabara T, McAllister C, Nussenblatt RR, Gery I. Adoptive transfer of experimental autoimmune uveoretinitis in rats: immunopathogenic mechanisms and histological features. Invest Ophthalmol Vis Sci 1985;26:1-9.

15. Liversidge J, Forrester JV. Experimental autoimmune uveitis (EAU): immunophenotypic analysis of inflammatory cells in chorioretinal lesions. Curr Eye Res 1988;7:1231-41.

16. Ando K. The influence of $\mathrm{H}-2$ genes and the effect of T cell depletion on experimental autoimmune uveoretinitis (EAU). Invest Ophthalmol Vis Sci 1993;34:S1480.

17. Rao NA. Suppression of experimental uveitis in rats by anti-I.A antibodies. Invest Ophthalmol Vis Sci 1989;30: 2348-55.

18. Wetzig R. Anti-Ia antibody diminishes ocular inflammation in experimental autoimmune uveitis. Curr Eye Res 1988;7:809-18.

19. Higuchi M. Combined anti-interleukin-2 receptor and low dose cyclosporin therapy in experimental autoimmune uveoretinitis. J Autoimmun 1991;4:113-24.

20. Montes C. Treatment of murine experimental autoimmune uveoretinitis with $\mathrm{T}$ cell receptor (TCR) V-beta specific antibody. Invest Ophthalmol Vis Sci 1992;33 (Suppl):S934.

21. Whitcup SM, Debarge LR, Caspi RR, Harning R, Nussenblatt RB, Chan CC. Monoclonal antibody against ICAM-1 (CD 54) and LFA-1 (CD11a/CD18) inhibit experimental autoimmune uveitis. Clin Immunol Immunopathol 1993;67:143-50. 
22. Jerne NK. Idiotypic network and other preconceived ideas. Immunol Rev 1984;79:5-24.

23. de Kozak Y, Mirshahi M, Boucheix C, Faure JP. Inhibition of experimental autoimmune uveoretinitis in rats by S-antigen specific antibodies. Eur J Immunol 1985;15:1107-11.

24. de Kozak Y, Mirshahi M, Boucheix C, Faure JP. Prevention of experimental autoimmune uveoretinitis by active immunization with autoantigen-specific monoclonal antibodies. Eur J Immunol 1987;17:541-7.

25. Dua HS, Liversidge J, Forrester JV. Immunomodulation of experimental autoimmune uveitis using a rat anti-retinal S-antigen specific monoclonal antibody: evidence for a species difference. Eye 1989;3:69-78.

26. Dua HS, Sewell HF, Forrester JV. The effect of retinal S-antigen specific monoclonal antibody therapy on experimental autoimmune uveoretinitis and experimental autoimmune pinealitis. Clin Exp Immunol 1989; 75:100-5.

27. Stiemer RH, Gausepohl H, Mirshahi M, de Kozak Y, Kraft M, Faure JP, Frank R. Immunological characterisation of an immunomodulatory epitope in S-antigen/ arrestin with a sequence motif common to tumor necrosis factor- $\alpha$. Immunol Lett 1992;32:233-40.

28. Stiemer RH, Westenfelder U, Gausepohl H, Mirshahi M, Gundt A, Frank R, Männel D. A common epitope in human tumor necrosis factor alpha and the autoantigen 'S-Antigen/Arrestin' induces TNF alpha production. J Autoimmun 1992;5:15-26.

29. de Kozak Y, Hicks D, Chatenoud L, Bellot J, Thillaye $\mathrm{B}$, Faure JP. Intraocular TNF endotoxin- and Santigen-induced uveitis: in vitro synthesis of TNF by retinal Müller glial and pigment epithelial cells. Reg Immunol 1994;6:76-80.

30. de Kozak Y, Naud MC, Bellot J, Faure JP, Hicks D. Differential tumor necrosis factor expression by resident retinal cells from experimental uveitis-susceptible and -resistant rat strains. J Neuroimmunol 1994;55:1-9.

31. De Vos AF, van Haren MAC, Verhagen C, Hoekzema R, Kijlstra A. Kinetics of intraocular tumor necrosis factor and interleukin-6 in endotoxin-induced uveitis in the rat. Invest Ophthalmol Vis Sci 1994;35:1100-6.

32. Lightman S, Palestine AG, Nussenblatt RB. Immunohistopathology of experimental immunogenic uveitis induced by a non-ocular antigen. Curr Eye Res 1986;5: 857-62.

33. Matsumoto K, Masaoka T, Nakamura T. Therapeutic evaluation on combination therapy with IG-100, pH4treated human immunoglobulin preparation for iv administration, and antibiotics against severe infections. Jpn J Infect Dis 1984;58:1001-24.

34. Dwyer JM. Manipulating the immune system with immune globulin. N Engl J Med 1992;326:107-16.

35. Kaveri SV, Dietrich G, Hurez V, Kazatchkine MD. Intravenous immunoglobulins (IVIg) in the treatment of autoimmune diseases. Clin Exp Immunol 1991;86: 192-8.

36. Imbach P, Barandun S, d'Apuzzo V, Baumgartner C, Hirt A, Morell A, et al. High-dose intravenous gammaglobulin for idiopathic thrombocytopenic purpura in childhood. Lancet 1981;1:1228-31.

37. Vermeulen M, Van Der Meche FGA, Speelman JD, Weber A, Busch HFM. Plasma and gamma-globulin infusion in chronic inflammatory polyneuropathy. J Neurol Sci 1985;70:317-26.

38. Furusho K, Kamiya T, Nakano H. High-dose intravenous gammaglobulin for Kawasaki disease. Lancet 1984;1:1055-8.
39. Le Hoang P, Jobin D, Kuhlmann N, Kazatchkine MD. Treatment of birdshot retinochoroidopathy with intravenous immunoglobulin (IVIg) (Submitted).

40. Abdelhadi S, Hurez V, de Kozak Y, Kuhn J, Kaveri SV, Kazatchkine MD, et al. Human immunoglobulin preparations for intravenous use prevent experimental autoimmune uveoretinitis. J Immunol 1993;5:1559-67.

41. Charteris DG, Lightman SL. Interferon gamma (IFN- $\gamma$ ) production in vivo in experimental autoimmune uveoretinitis. Immunology 1992;75:463-7.

42. Charteris DG, Lightman SL. In vivo lymphokine production in experimental autoimmune uveoretinitis. Immunology 1993;78:387-92.

43. Dietrich G, Kaveri SV, Kazatchkine MD. Modulation of autoimmunity by intravenous immune globulin through interaction with the function of the immune/ idiotypic network. Clin Immunol Immunopathol 1992;62:S73-81.

44. Shimozato T, Iwata M, Tamura N. Suppression of tumor necrosis factor alpha production by a human immunoglobulin preparation for intravenous use. Infect Immun 1990;58:1384-90.

45. Shimozato T, Iwata M, Kawada H, Tamura N. Human immunoglobulin preparation for intravenous use induces elevation of cellular cyclic adenosin $3^{\prime}: 5^{\prime}$ monophosphate levels, resulting in suppression of tumor necrosis factor alpha and interleukin-1. Immunology 1991;72:497-501.

46. Andersson JP, Andersson UG. Human intravenous immunoglobulin modulates monokine production in vitro. Immunology 1990;71:372-6.

47 Andersson UG, Bjork L, Skansen SU, Andersson JP. Down-regulation of cytokine production and interleukin-2 receptor expression by pooled IgG. Immunology 1993;79:211-16.

48. Abe Y, Horiuchi M, Kimura S. Anti-cytokine nature of human immunoglobulin: one possible mechanism of the clinical effect of intravenous immunoglobulin therapy. In: Möller G, editor. Immunological reviews, vol 139, Immunoglobulin treatment: mechanisms of action. Copenhagen: Munksgaard, 1994:5-21.

49. Kazatchkine MD, Dietrich G, Hurez V, Ronda N, Bellon B, Rossi F, Kaveri SV. V region-mediated selection of autoreactive repertoires by intravenous immunoglobulin (i.v.Ig). In: Mölle G, editor. Immunoglobulin reviews, vol 139 , Immunoglobulin treatment: mechanisms of action. Copenhagen: Munksgaard, 1994:79-107.

50. Whitcup SM, DeBarge LR, Rosen H, Nussenblatt RB, Chan C. Monoclonal antibody against C11b/CD18 inhibits endotoxin-induced uveitis. Invest Ophthalmol Vis Sci 1993;34:673-81.

51. Kogiso M, Tanouchi $Y$, Mimura $Y$, Nagasawa $H$, Himeno K. Endotoxin-induced uveitis in mice. I. Induction of uveitis and role of T lymphocytes. Jpn J Ophthalmol 1992;36:281-90.

52. Fehr J, Hofmann V, Kappeler U. Transient reversal of thrombocytopenia in idiopathic thrombocytopenic purpura by high-dose intravenous gammaglobulin. $\mathrm{N}$ Engl J Med 1982;306:1254-8.

53. Cassoux N, Haroun O, George F, Bodaghi B, Kullmann N, Jobin D, LeHoang P, Kazatchkine MD. Effect of intravenous immunoglobulin (IVIg) in the treatment of birdshot retinochoroidopathy. Invest Ophthalmol Vis Sci 1996;37 (Suppl):S369.

54. Doekes G. Humoral and cellular immune responsiveness to human S-antigen in uveitis. Curr Eye Res 1987; 6:909-19. 
55. Forrester JV, Scott DI, Hercus KM. Naturally occurring antibodies to bovine and human retinal $\mathrm{S}$ antigen: a comparison between uveitis patients and healthy volunteers. Br J Ophthalmol 1989;73:155-9.

56. Hoekzema R. Serum antibody response to human and bovine IRBP in uveitis. Curr Eye Res 1990;9:1177-83.

57. Dumonde DC, Kasp-Grochowska E, Graham E, Sanders MD, Faure JP, de Kozak Y, van Tuyen V. Anti-retinal autoimmunity and circulating immune complexes in patients with retinal vasculitis. Lancet 1982:2:787-92.

58. Gregerson DS, Abrahams IW, Thirkill CE. Serum antibody levels of uveitis patients to bovine retinal antigens. Invest Ophthalmol Vis Sci 1981;21:669-80.

59. Chan CC. Anti-retinal autoantibodies in Vogt-Koyanagi-Harada's syndrome, Behçet's disease and sympathetic ophthalmia. Clin Immunol Immunopathol 1985; 35:103-10.

60. Klok AM, de Vries J, Rothova A, Zaal MJ, Schweitzer CM, Bos JD, Kijlstra A. Antibodies against ocular and oral antigens in Behçet's disease associated with uveitis. Curr Res 1989;8:957-62.

61. Michaelson JB, Chisari FV, Kansu T. Antibodies to oral mucosa in patients with ocular Behçet's syndrome. Ophthalmology 1985;92:1227-81.

62. Fenton RM. The use of indirect immunofluorescence testing and guinea pig lip mucosa for the evaluation of Behçet's and non-Behçet's uveitis. Invest Ophthalmol Vis Sci 1992;33 (Suppl):S942.
63. Kasp E. Antibody affinity to retinal S-antigen in patients with retinal vasculitis. Am J Ophthalmol 1992:113:697-701.

64. Polans AS, Burton MD, Haley TL, Crabb JW, Palczewski K. Recoverin, but not visinin, is an autoantigen in the human retina identified with a cancer-associated retinopathy. Invest Ophthalmol Vis Sci 1993;34:81-90.

65. Milan AH, Saari JC, Jacobson SG, Lubinski WP, Feun LG, Alexander R. Autoantibodies against retinal bipolar cells in cutaneous melanoma-associated retinopathy. Invest Ophthalmol Vis Sci 1993;34:91-100.

66. Levinsky RJ. Circulating soluble immune complexes in recurrent oral ulceration and Behçet's syndrome. Clin Exp Immunol 1978;32:193-8.

67. O'Connor GR. Factors related to the initiation and recurrences of uveitis. Am J Ophthalmol 1983;96: 577-99.

68. Dernouchamps JP. Immune complexes in the aqueous humour and serum. Am J Ophthalmol 1977;84:24-31.

69. Stanford MR. A longitudinal study of clinical and immunological findings in two patients with retinal vasculitis. Br J Ophthalmol 1988;72:442-7.

70. de Smet MD, Yamamoto JH, Mochizuki M, Gery I, Singh VK, Shinohara T, Wiggert B, Nussenblatt RR. Cellular immune responses of patients with uveitis to retinal antigens and their fragments. Am J Ophthalmol 1990;110:135-42. 